\title{
PENGEMBANGAN TEORI PEMBENTUKAN PERILAKU KEAGAMAAN
}

\author{
Joko Subando \\ Fakultas Tarbiyah, Institut Islam Mamba'ul 'Ulum Surakarta, \\ Email: jokosubando@yahoo.co.id
}

\begin{abstract}
This study aims to develop a theory of the formation of religious behavior which can be used as a tool to analyze patterns of internalization of understanding of religious schools in Indonesia. The development of this theory was built at the Al-Irsyad religious organization on the grounds that this organization has long been established, this organization is able to manifest Al-Irsyad's distinctive religious behavior and can recruit followers among non-Arab communities. This study uses a mixed method approach (quantitative-qualitative). The quantitative approach is used to obtain mathematical equations in the model of religious behavior formation, while the qualitative approach is used to analyze the findings of mathematical equations to make them more meaningful. Al-Irsyad student respondents in Java were 729 students. The technique of collecting data by means of interviews, documentation and questionnaires. Qualitative data were analyzed descriptively qualitative, while quantitative data were analyzed using Confirmatory Factor Analysis (CFA). The results showed that:

1) the process of forming religious behavior is determined by curriculum design, 2) the formation of religious attitudes is determined by the process of forming attitudes which combines the quality of interaction with a comprehensive method and determined by the design of the desired attitude in the curriculum, 3) religious behavior is largely determined by the attitude and design of the desired behavior in the curriculum.
\end{abstract}

Keywords: behavior formation theory, religious behavior

\section{PENDAHULUAN}

Pada bulan April 2021 berkembang sebuah aliran baru di Biak dan kota Supiori yang merupakan sempalan dari ajaran kristiani. Berita tersebut menjadi viral dan menyedot banyak perhatian warga khususnya masyarakat dunia maya. Pemerintah melalui Kementerian Agama (Kemenag) dan Satuan Polisi Pamong Praja (Satpol PP) telah membubarkan tempat mereka biasa berkumpul dan menyita beberapa barang bukti seperti baliho yang berisi gambar Tuhan mereka. Aliran baru ini memiliki pengikut sampai 100 orang. Ritual yang dianggab aneh dari aliran ini yaitu mereka berjalan tanpa busana di malam hari menuju bukit kemudian mereka melakukan hubungan badan hingga pagi hari. Mereka yang tidak melakukan hubungan badan dianggab tidak melakukan perintah Tuhan. ${ }^{1}$

Satu bulan sebelumnya yaitu Maret 2021 juga viral aliran Hakekok Balakasuta. Aliran ini dipimpin oleh Ary yang mengajarkan kepada 16 orang pengukitnya mandi dan berendam di rawa tanpa busana. Aliran sesat ini melakukan perkumpulan setiap minggu wage diawali dengan pembacaan kidung dalam Bahasa Sunda dan dilanjutkan dengan pengajian. Setiap orang yang akan bergabung dengan aliran tersebut harus bersyahadat dengan kalimat "Sahadatan ala ila ha illah wasahadatan ala saidin muhammad ama sepuh." Kalimat

\footnotetext{
${ }^{1}$ Anonim, Aliran apa ini? Naik ke Bukit Tanpa Busana, Tuhannya Menerima, diakses dari JPPN.Com, Kamis, 22 April 2021 - 23:01 WIB
} 
persaksian tersebut mengakui bahwa tidak ada Tuhan yang pantas disembah kecuali ama sepuh. Ary merupakan utusan ama sepu sekaligus pemimpin hakekok balakasuta. ${ }^{2}$

Di negeri ini aliran sesat tumbuh subur, menurut Majelis Ulama Indonesia (MUI) Sumatera Utara, aliran-aliran sesat yang muncul sebelum tahun 2010 cukup banyak antara lain: Al qur'an suci, Hidup di Balik Hidup (HDP), Surga Edn (2009), Sekte Satria Piningit Weteng Buwono (2009) dan lain sebagainya. Aliran Al qur'an suci muncul tahun 2007, aliran ini seperti ingkar sunah atau Negara Islam Indonesia Kavalieri (NII KW) IX yang meyakini bahwa sumber hukum dalam Islam hanya Al-Qur'an. Aktivitas yang dilakukan dalam jamaah ini adalah mengajak untuk hijrah. Mentor dalam aliran ini menjelaskan beberapa langkah dalam hijrah: 1) menjelaskan nikmat Allah yang diberikan kepada calon jamaah, 2) melaksanakan hijrah, 3) mendapatkan janji yang akan diberikan setelah hijrah, 4) hijrah dilakukan secara rahasia. Hal-hal yang menyimpang dalam ajaran ini adalah sholat tanpa wudlu dan diperobolehkan menzinai saudara ipar. ${ }^{3}$

Aliran HDP juga muncul tahun 2007, aliran ini didirikan oleh Muhammad Kusnan tahun 1940 dan di dalam buku pedoman HDP menyatakan bahwa Muhammad ali bin Abdullah alias Mujdoni adalah penerusnya. Hal-hal yang menyimpang dalam aliran ini adalah tidak meyakini syafaat Nabi Muhammad, dan meyakini bahwa Muhammad Kusnan pernah melakukan perjalanan ke Sidratul Muntaha, bahkan perjalanan ke Surga dan melihat Neraka sebagaimana Isra'Mi'raj Nabi Muhammad Saw. ${ }^{4}$

Setelah tahun 2010, aliran sesat bukan berkurang tapi justru semakin bertambah. Menurut Catatan MUI Sumatra Utara Aliran sesat yang muncul setelah 2010 antara lain: Mukmin Mubalighah (2010), Naqsabandiyah Kholidiyah Dermaga Muhammad Syukur (2014), Amanat Keagungan Ilahi (2016), Gerakan Fajar Nusantara/Gafatar (2016), Ajaran Pedepokan Dimas Kanjeng (2016), Tarekat Tajul Al Khalwatiyah (2016), Salat Menghadap Timur (2020), Melihat Tuhan Melalui Cahaya (2019) dan lain sebagainya.

Aliran Salat menghadap ke timur muncul tahun 2020, aliran ini diajarkan oleh Mahrawi di desa Lebak Kecamatan Sangkawung. Selain salat menghadap ke timur yang dianggap ritual sesat, aliran ini memiliki aktivitas yang aneh yaitu wirid dengan menyilangkan tangan di dada. Aliran ini telah memiliki pengikut sebanyak 30 orang.

Aliran lain yang viral satu tahun sebelumnya yaitu Melihat Tuhan melalui cahaya, aliran ini berkembang di Mamuju, melalui pengajian rutin. Dengan membayar uang sebesar Rp 300 sd 700 ribu anggota jamaah dapat melihat dzat Allah melalui cahaya.

Dari fakta sosial di atas, hal yang menarik untuk dikaji selain bagaimana kesesatan aliran tersebut adalah bagaimana aliran tersebut melakukan internalisasi pemahaman dan ideologi terhadap para jamaah atau pengikutnya. Hal ini penting untuk diketahui agar dapat melihat pola gerakan dan dapat dilakukan upaya pencegahan serta penghentian gerakan aliran sesat. Namun demikian untuk mendalami proses internalisasi pemahaman pada kelompok atau aliran sesat di atas membutuhkan dasar teori yang kuat sebagai pisau analisisnya.

Ada beberapa teori yang dapat dijadikan sebagai dasar untuk mengungkap permasalahan tersebut yaitu teori perilaku sosial. Teori perilaku sosial menyatakan bahwa

\footnotetext{
${ }^{2}$ Anonim, Aliran Sesat Hakekok Balakasuta, diakses dari JPPN. Com, Jumat, 12 Maret 2021 - 19:51 WIB

${ }^{3}$ Matondang, H. A., \& Rangkuti, S. M. Kajian dan Penelitian Fatwa-Fatwa Mui Tentang Aliran Sesat. (Medan: CV Manhaji, 2020) hal. 5-52

${ }^{4}$ Matondang, H. A., \& Rangkuti, S. M, hal. 8
} 
perilaku seseorang ditentukan oleh niat atau minat, sedangkan niat atau minat seseorang sangat ditentukan oleh sikap, dan norma subyektif. Teori ini dinamakan teori perilaku beralasan. Seiring dengan perjalanan waktu teori ini berkembang menjadi teori perilaku berencana (TPB). Menurut TPB perilaku sosial seseorang ditentukan oleh minat sedangkan minat atau niat seseorang selain ditentukan oleh norma subyektif, sikap dan juga ditentukan oleh kontrol sosial. ${ }^{5}$

Namun demikian, sebenarnya Teori perilaku sosial dikonstruk dalam latar belakang sosial kapitalis bukan sosial religius. Masing-masing latar sosial memiliki perilaku kehidupan yang khas yaitu spirit keagamaan di kehidupan sosial religius mendorong seseorang berperilaku, namun perilaku di lingkungan kapitalis karena dorongan material. Berpijak dari hal di atas maka perlu ada pengembangan teori perilaku sosial dalam bidang keagamaan. Teori perilaku keagamaan ini penting karena dapat digunakan untuk mengungkap bagaimana aliran sesat melakukan internalisasi nilai sehingga membentuk sikap dan perilaku seperti yang dikehendaki dari pimpinan organisasi atau aliran yang ada.

Penelitian ini bukan untuk melihat proses internalisasi atau pola rekrutmen pada aliran- aliran di atas. Namun penelitian ini bertujuan untuk menyiapkan fasilitas berupa teori perilaku keagamaan yang dapat dijadikan sebagai pisau analisis yang akan membantu peneliti ketika melakukan penelitian lapangan pada aliran-aliran sesat di atas. Penelitian ini bertujuan untuk mengembangkan teori perilaku keagamaan. Teori ini dibangun dari organisasi keagamaan yang sudah eksis lama dan memiliki pengaruh yang besar. Penelitian ini menggunakan lokus organisasi Al-Irsyad bukan Muhammadiyah atau Nahdatul Ulama (NU) karena beberapa alasan. Pertama Al-Irsyad merupakan organisasi keagamaan yang sudah berdiri sejak lama dan hingga saat ini masih eksis. Organisasi ini didirikan 6 September 1914 jadi hingga sekarang sudah satu abad lebih keberadaannya. Kedua, organisasi ini mampu mengikat pengikutnya dengan kuat dan mampu memunculkan perilaku keagamaan yang khas dengan mabadi atau ideologi Al-Irsyad. Ketiga organisasi ini dikembangkan oleh komunitas Arab namun tumbuh subur dengan pengikut yang banyak di kalangan luar komunitas Arab. Kemampuan organisasi Al-Irsyad untuk terus tumbuh dan berkembang dan mampu merekrut anggota di luar komunitasnya dipastikan karena memiliki pola pembentukan perilaku keagamaan yang khas. Atas dasar pertimbangan tersebut maka layak bila organisasi tersebut dikaji bagaimana pengembangan perilaku keagamaan di Al-Irsyad.

\section{METODE PENELITIAN}

1. Jenis Penelitian

Penelitian ini menggunakan pendekatan mixed method (kuantitatif-kualitatif). Penelitian kuantitatif untuk mendapatkan model teori perilaku sedangkan penelitian kualitatif untuk mendapatkan deskripsi teori yang berhasil dikembangkan.

2. Data dan Sumber Data

Data yang dibutuhkan dalam penelitian ini yang terdiri dari data kuantitatif dan data kualitatif. Data kuantitatif berupa data isian angket yang dibagikan oleh peneliti kepada responden tentang desain kurikulum, proses penguatan nilai keagamaan, sikap, pandangan

${ }^{5}$ Fishbein, M. A., Icek. (1975). Belief, Attitude, Intention, dan Behavior: an introduction to theory and research. London: Addison, Wesley Publishing Company. Baca juga Fishbein, M. A., Icek. (1980). Understanding attitude and predicting social behavior. Englewood Cliffs NJ: Prentice Hall. 
dan perilaku yang mencerminkan nilai keagamaan organisasi. Sedangkan data kualitatif berupa narasi dan buku-buku literatur yang terkait dengan sikap, pandangan dan perilaku yang mencerminkan nilai keagamaan, proses penguatan nilai keagamaan dan desain pembentukan sikap dan perilaku dalam kurikululum pendidikan.

3. Teknik Pengumpulan Data

Teknik pengumpulan data melalui wawancara, dokumentasi dan angket kuesioner. Wawancara dan dokumentasi untuk mengumpulkan data sikap dan perilaku keagamaan, angket kuesioner untuk mengumpulkan data desain kurikulum, proses penguatan nilai keagamaan, sikap, pandangan dan perilaku yang mencerminkan nilai keagamaan organisasi. Dokumentasi digunakan untuk mengumpulkan data dari berbagai literatur yang terkait.

4. Instrumen Penelitian

Instrumen penelitian yang digunakan terdiri angket esain, proses, output dan outcome yang dikembangkan oleh Subando, Kartowagiran dan Munadi ${ }^{6}$. Angket desain memiliki empat indikator yang mencakup tujuan, konten, aktivitas pembelajaran dan evaluasi pembelajaran. Angket proses terdiri tiga indikator meliputi dukungan emosional, manajemen kelas, dan dukungan instruksional. Angket output meliputi sikap dan pandangan yang mencerminkan delapan aspek ideologi yaitu sumber hukum tauhid, ibadah, akhlak, kesetaraan, pengetahuan, modernitas dan ukhuwah. Angket outcome berua perilaku yang mencerminkan delapan aspek ideologi di atas. Instrumen telah memenuhi kriteria validitas instrumen hal ini ditunjukkan dari nilai nilai SLF >0,7, CR>0,7 dan AVE>0,5 lihat tabel 1.

Tabel 1. Validitas Instrumen

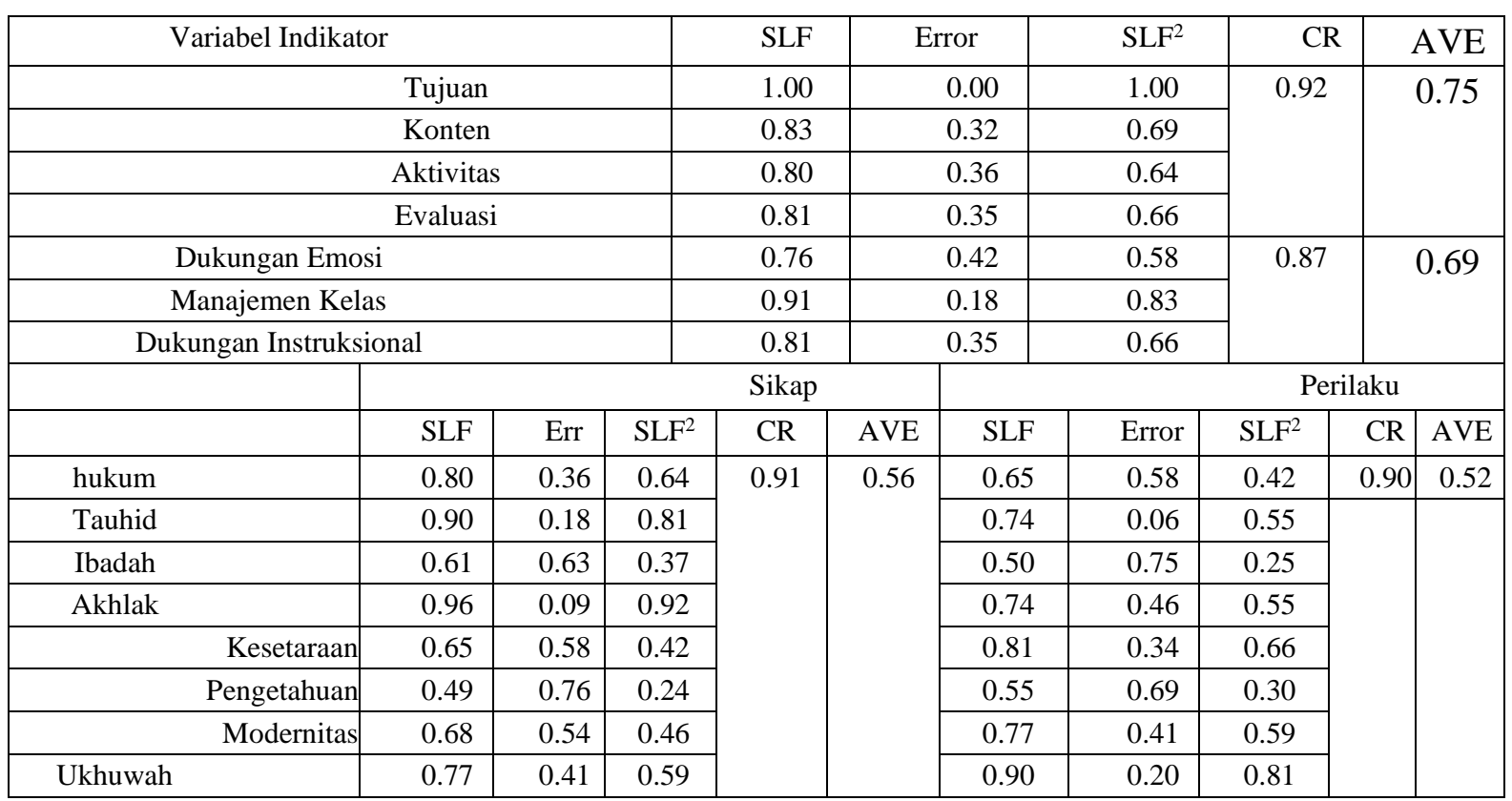

Sumber: hasil olah data

\footnotetext{
${ }^{6}$ Subando, J., Kartowagiran, B., \& Munadi, S. (2020a). Constructions of Al-Irsyad's Ideology. Paper presented at the International Conference of Social Sciences and Education 2020, Yogyakarta, Indonesia. Baca juga Subando, J., Kartowagiran, B., \& Munadi, S. (2020b). The Development of Instrument for Evaluating The Process of Strengthening Religion Ideology. Paper presented at the Proceedings of the 4th International Conference on Learning Innovation and Quality Education. Subando, J., Kartowagiran, B., \& Munadi, S. (2020c). Pengembangan Instrumen Indeks Ketahanan Ideologi Al-Irsyad Komponen Perilaku. Prosiding Seminar virtual pendidikan Kewarganegaraan 2020 UNS, 1(1), 406-413.
} 
Instrumen juga memenuhi persyaratan reliabilitas isntrumen karena nilai cronbach alpha $>0,7$, lihat tabel 2 .

Tabel 2. Nilai estimasi Reliabilitas Instrumen

\begin{tabular}{|c|l|c|c|}
\hline \multicolumn{1}{|c|}{ Dimensi } & \multicolumn{1}{|c|}{ Aspek } & \multicolumn{2}{|c|}{0,832} \\
\hline \multirow{5}{*}{ Desain } & Tujuan & \multicolumn{2}{|c|}{0,852} \\
\cline { 2 - 4 } & Konten Kurikulum & \multicolumn{2}{|c|}{0,713} \\
\cline { 2 - 4 } & Aktivitas & \multicolumn{2}{|c|}{0,821} \\
\cline { 2 - 4 } & Evaluasi & \multicolumn{2}{|c|}{0,702} \\
\hline \multirow{5}{*}{ Proses } & Dukungan emosional & \multicolumn{2}{|c|}{0,705} \\
\cline { 2 - 4 } & Manajemen kelas & Output & 0,706 \\
\cline { 2 - 4 } & Dukungan intruksional & 0,823 & 0,702 \\
\hline & & 0,796 & 0,739 \\
\cline { 2 - 4 } & Sumber hukum & 0,808 & 0,728 \\
\cline { 2 - 4 } & Tauhid & 0,941 & 0,701 \\
\cline { 2 - 4 } & Ibadah & 0,754 & 0,717 \\
\cline { 2 - 4 } & Akhlak & 0,831 & 0,721 \\
\cline { 2 - 4 } & Kesetaraan & 0,936 & 0,733 \\
\cline { 2 - 4 } & Pengetahuan & 0,892 & \\
\cline { 2 - 4 } & Modernitas & & \\
\cline { 2 - 4 } & Ukhuwah Islamiyah & & \\
\end{tabular}

Sumber: hasil olah data

\section{Teknik Analisis Data}

Data kuantitatif di analisis dengan statistik inferensial yaitu Confirmatory Factor Analysis (CFA) sedangkan data kualitatif di analisis secara deskriptif kualitatif. CFA digunakan untuk membuktikan validitas konstruk instrumen. Menurut Ghozali dan Fuad $\underline{(2014)}^{7}$ serta Latan $(2013)^{8}$ model dikatakan fit apabila memenuhi kriteria:

$\chi^{2} / d f<2, \mathrm{P}$ value $\geq 0,05, \mathrm{RMSEA} \leq 0,08, \mathrm{NFI} \geq 0,9, \mathrm{NNFI} \geq 0.9, \mathrm{CFI} \geq 0.9, \mathrm{IFI} \geq 0.9$, $\mathrm{GFI} \geq 0.9, \mathrm{~A} \overline{\mathrm{GFI}} \geq 0.9$.

\section{HASIL DAN PEMBAHASAN}

\section{Hasil penelitian}

Hasil penelitian pengembangan menunjukkan bahwa teori perilaku keagamaan adalah seperti tampak dalam struktur model di bawah:

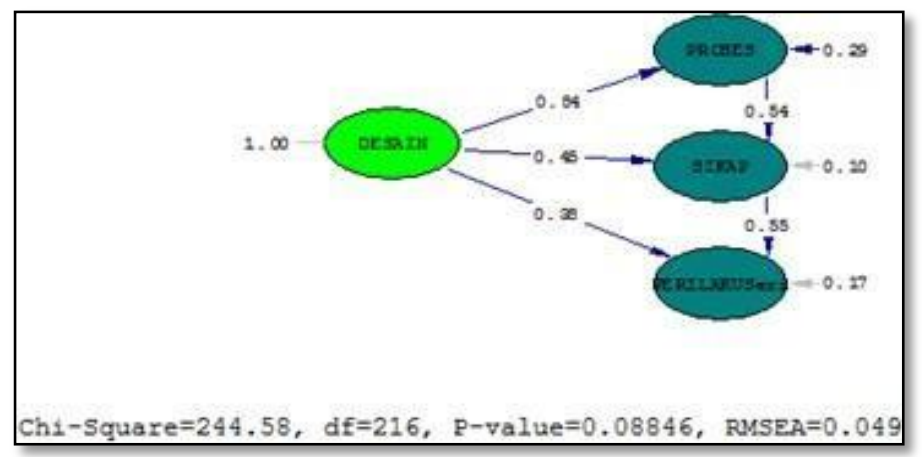

Gambar 1. Struktur Model Pengembangan Teori Perilaku Keagamaan

\footnotetext{
${ }^{7}$ Ghozali, I., \& Fuad, S. E. M. Teori, Konsep dan Aplikasi dengan Program Lisrel 9.10. (Badan Penerbit Universitas Diponegoro, 2014) Hal. 29-35

${ }^{8}$ Latan, H.Structural equation modeling: Konsep dan aplikasi menggunakan program LISREL 8.80. (Bandung: Alfabeta, 2013) hal. 53
} 
Model di atas di bangun dari komponen model yang telah memenuhi kriteria kelayakan model, hal ini nampak dari tabel 3.

Berpijak struktural model di atas maka dapat diperoleh bentuk-bentuk persamaan sebagai berikut

\section{1) Proses $=0.84 *$ Desain}

Persamaan struktural di atas menunjukan bahwa proses penguatan nilai keagamaan berkorelasi positif dengan desain nilai keagamaan yang akan diwujudkan, semakin baik desain dalam penguatan nilai keagamaan maka semakin baik pula proses penguatannya. Berdasar output dalam lisrell, nilai korelasi kedua variabel sebesar $\mathrm{R}=0,84$ dan $\mathrm{R}^{2}=0,71$ artinya $71 \%$ proses penguatan nilai keagamaan ditentukan oleh desainnya. ${ }^{9}$

Tabel 3. Kriteria Kelayakan Model

\begin{tabular}{|c|c|c|c|c|c|c|}
\hline Dimensi & Aspek & FL & T-value & P-value & $\begin{array}{c}\text { Chi- } \\
\text { square/df }\end{array}$ & RMSEA \\
\hline \multirow{4}{*}{$\begin{array}{l}\text { Z } \\
\text { 岕 } \\
\text { 至 } \\
\text { 至 }\end{array}$} & Tujuan & $>0,36$ & $>2,58$ & 0,17833 & 1,2 & 0,062 \\
\hline & Konten Kurikulum & $>0,54$ & $>3,63$ & 0,08137 & 1,31 & 0,078 \\
\hline & Aktivitas & $>0,41$ & $>3,12$ & 0,73343 & 0,597 & 0 \\
\hline & Evaluasi & $>0,70$ & $>5,61$ & 0,99247 & 0,005 & 0 \\
\hline \multirow[b]{3}{*}{ 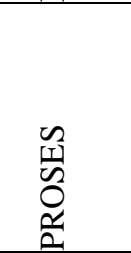 } & $\begin{array}{l}\text { Dukungan } \\
\text { emosional }\end{array}$ & $>0,34$ & $>3,37$ & 0,89193 & 0,21 & 0 \\
\hline & Manajemen kelas & $>0,37$ & $>3,22$ & 0,34469 & 1,09 & 0,013 \\
\hline & $\begin{array}{l}\text { Dukungan } \\
\text { intruksional }\end{array}$ & $>0,32$ & $>1,96$ & 0,31541 & 1,1 & 0.018 \\
\hline \multirow{8}{*}{ 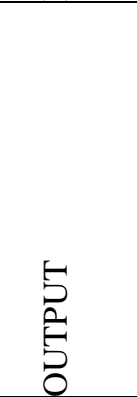 } & Sumber hukum & $>0,9$ & & 1 & 0 & 0 \\
\hline & Tauhid & $>0,47$ & $>9,59$ & 0,10688 & 1,47 & 0,032 \\
\hline & Ibadah & $>0,91$ & & 1 & 0 & 0 \\
\hline & Akhlak & $>0,65$ & $>15,05$ & 0,07467 & 1,37 & 0,028 \\
\hline & Kesetaraan & $>0,72$ & $>17,87$ & 0,25535 & 1,29 & 0,025 \\
\hline & Pengetahuan & $>0,93$ & & 1 & 0 & 0 \\
\hline & Modernitas & $>0,56$ & $>10,96$ & 0,13424 & 1,39 & 0,029 \\
\hline & $\begin{array}{l}\text { Ukhuwah } \\
\text { Islamiyah }\end{array}$ & $>0,63$ & $>14,25$ & 0,62159 & 0,475 & 0 \\
\hline \multirow{8}{*}{$\begin{array}{l}\sum_{0}^{\Perp} \\
0 \\
0 \\
0\end{array}$} & Sumber hukum & $>0,43$ & $>0,854$ & 0,60587 & 0,27 & 0 \\
\hline & Tauhid & $>0,61$ & $>14,79$ & 0,26348 & 1,25 & 0,023 \\
\hline & Ibadah & $>0,32$ & $>2,42$ & 0,40448 & 0,69 & 0,015 \\
\hline & \begin{tabular}{|l|} 
Akhlak \\
\end{tabular} & $>0,34$ & $>6,60$ & 0,92208 & 0,08 & 0 \\
\hline & Kesetaraan & $>0,71$ & $>17,21$ & 0,80306 & 0,06 & 0 \\
\hline & Pengetahuan & $>0,48$ & $>8,10$ & 0,44065 & 0,59 & 0 \\
\hline & Modernitas & $>0,30$ & $>3,58$ & 0,21798 & 1,52 & 0,033 \\
\hline & $\begin{array}{l}\text { Ukhuwah } \\
\text { Islamiyah }\end{array}$ & $>0,32$ & $>5,52$ & 0,67982 & 0,39 & 0 \\
\hline
\end{tabular}

Hasil penelitian ini berbeda dengan temuan Kavgaoglu dan Alci (2016). ${ }^{10}$ Kavgaoglu dan Alci (2016) melakukan penelitian untuk mengevaluasi kurikulum di Turki. Komponen evaluasi mencakup, evaluasi konteks yang meliputi keserasian antara minat kebutuhan dan harapan, lingkungan pendidikan dan lama waktu pendidikan, evaluasi input meliputi desain

\footnotetext{
${ }^{9}$ Ghozali, I., \& Fuad, S. E. M. Teori, Konsep dan Aplikasi dengan Program Lisrel 9.10. (Badan Penerbit Universitas Diponegoro, 2014) Hal. 395

${ }^{10}$ Kavgaoglu, D., \& Alci, B. (2016). Application of Context Input Process and Product Model in Curriculum Evaluation: Case Study of a Call Centre. Educational Research and Reviews, 11(17), 1659-1669. doi: DOI: 10.5897/ERR2016.2911
} 
instruksional, materi pembelajaran, dan tema konten, evaluasi proses meliputi desain instruksional, manajemen proses, aktivitas, metode dan teknik instuksional, evaluasi output meliputi target-target dari kurikulum. Hasil penelitin menunjukkan bahwa konteks pembelajaran menentukan input yang berupa desain instruksional, namun hal tersebut tidak menentukan proses pembelajaran sebagaimana dalam prosedur CIPP, sedangkan input dan proses menentukan produk dari kurikulum, lihat gambar 1.

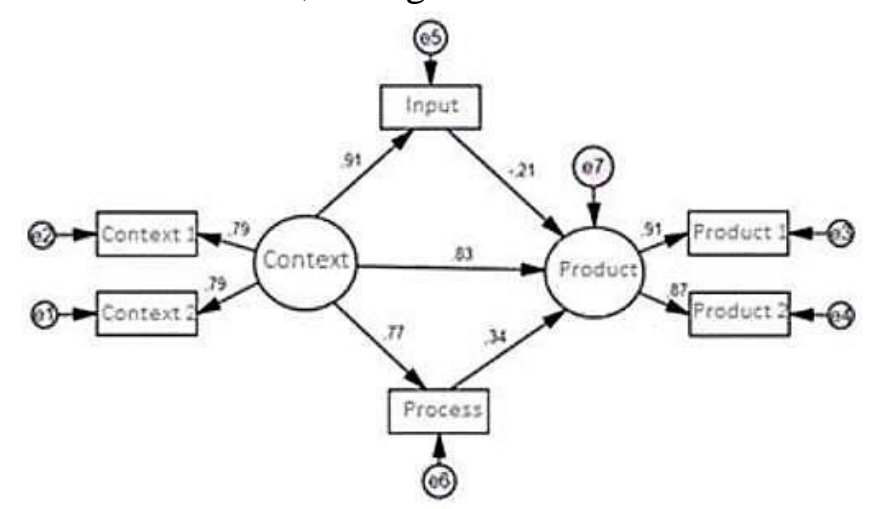

Gambar 2. Model CIPP dalam Evaluasi Kurikulum ${ }^{11}$

Hasil penelitian ini menyatakan bahwa desain sangat menentukan proses, hal ii dibuktikan adanya sumbangan efektif desain terhadap proses dalam penelitian ini sebesar $71 \%$ dengan nilai korelasi $\mathrm{r}=0,84$, . Desain meliputi tujuan, konten, aktivitas penguatan dan evaluasi akan membantu ustadz, kyai dalam berinteraksi dengan santri sehingga terjadi proses penguatan nilai keagamaan. Penelitian ini menguatkan temuan penelitian lain yang menyatakan bahwa desain kurikulum dalam pendidikan mempengaruhi proses pembelajaran seperti hasil penelitian Imansari dan Sutadji (2017), Darma (2019), Gultom, Sumarno, dan Madya (2014), Khuriyah, Zamroni, dan Sumarno (2016). ${ }^{12}$.

\section{2) Sikap $=1.72 *$ Proses $+1.41 *$ Desain}

Berdasar persamaan struktural di atas, sikap keagamaan dipengaruhi oleh proses penguatan nilai keagamaan dan desainnya, nilai koefisien variabel proses 1,72 dan nilai koefisien variabel desain 1,41 hal ini menunjukkan bahwa proses penguatan memiliki pengaruh yang lebih besar di bandingkan dengan desain. Berdasar output dalam lisrell nilai $\mathrm{R}^{2}=0,90$ artinya bahwa $90 \%$ sikap keagamaan santri ditentukan oleh proses dan desainnya, sisanya $10 \%$ ditentukan oleh variabel lain. ${ }^{13}$

Proses penguatan nilai keagamaan untuk memunculkan sikap keagamaan dalam penelitian ini berupa aktivitas interaksi guru, kyai, ustadz terhadap santri, dalam pengajian atau pembelajaran dengan metode komprehensif. Interaksi akan berkualitas bila ada

\footnotetext{
${ }^{11}$ Kavgaoglu, D., \& Alci, B. (2016). Application of Context Input Process and Product Model in Curriculum Evaluation: Case Study of a Call Centre. Educational Research and Reviews, 11(17), 1659-1669. doi: DOI: 10.5897/ERR2016.2911

${ }^{12}$ Imansari, N., \& Sutadji, E. (2017). A Conceptual Framework Curriculum Evaluation Electrical Engineering Education. International Journal of Evaluation and Research in Education, 6(4), 265-269. Baca juga Darma, I. K. (2019). The effectiveness of teaching program of CIPP evaluation model. International research journal of engineering, IT \& scientific research, 5(3), 1-13. doi: https://doi.org/10.21744/irjeis.v5n3.619. Gultom, M., Sumarno, S., \& Madya, S. (2014). Model Evaluasi Reflektif Kurikulum Pendidikan Bahasa Inggris Dalam Pengembangan Karakter Bangsa. Jurnal Penelitian dan Evaluasi Pendidikan, 18(1), 72-88. doi:

${ }^{13}$ Ghozali, I., \& Fuad, S. E. M. Teori, Konsep dan Aplikasi dengan Program Lisrel 9.10. (Badan Penerbit Universitas Diponegoro, 2014) Hal. 395
} 
dukungan emosional, manajemen kelas dan dukungan instruksional, hal ini sebagaimana penelitian Allen et al. (2013) $)^{14}$, Pianta, Hamre, dan Stuhlman (2003) ${ }^{15}$, Pianta dan Hamre $(2009)^{16}$, Pianta, Hamre, dan Allen(2012) ${ }^{17}$, bahwa ketiga variabel tersebut menentukan kualitas interaksi. Sikap keagamaan akan kuat bila menggunakan metode komprehensif yang mencakup inkulkasi, keteladanan, fasilitasi nilai dan pengembangan ketrampilan akademik dan sosial. ${ }^{18}$

Hal-hal di atas sesuai dengan pernyataan D. Zuchdi (1995) yang menyatakan bahwa sikap dibentuk oleh interaksi social. Dan, menurut Azwar (2007) bahwa faktor-faktor yang mempengaruhi sikap adalah: pertama, pengalaman pribadi, seseorang yang tidak memiliki pengalaman pribadi maka akan memiliki sikap negatif terhadap obyek sikap. Lebih lanjut, pemberian pengalaman pribadi melalui pembelajaran akan menjadikan siswa memiliki sikap yang kuat terhadap obyek sikap, desain kurikulum yang memuat pengalaman belajar dan proses pembelajaran yang memfasilitasi siswa akan menjadikan siswa memiliki emosi positif sehingga sikap tersebut muncul.

Kedua, pengaruh kebudayaan, budaya-budaya religious di sekolah, masyarakat, masjid akan memunculkan sikap positif terhadap obyek sikap religius tersebut. Budayabudaya keagamaan dapat dibangun melalui pembiasaan-pembiasaan yang sudah diprogramkan oleh organisasi atau sekolah. Ketiga, media massa, informasi-informasi yang muncul di media massa akan berpengaruh terhadap sikap siswa. Pengembangan sikap kritis terhadap informasi perlu dilakukan agar sikap positif yang diinginkan tercapai. Sehingga, pengajian dan pembelajaran harus mengembangkan sikap kritis tersebut.

Keempat lembaga pendidikan dan organisasi, ajaran-ajaran dari lembaga pendidikan dan organisasi akan membentuk sikap. Dalam penelitian ini ajaran- ajaran organisasi yang dimaksud adalah nilai-nilai keagamaan yang diajarkan di Al-Irsyad, sehingga desain yang memuat nilai-nilai keagamaan akan membentuk sikap santri atau siswa.

\section{3) Perilaku $=0.42 *$ Sikap $+0.93 *$ Desain}

Berdasar persamaan struktural di atas, perilaku keagamaan dipengaruhi oleh sikap dan desain tentang nilai keagamaan.. Nilai koefisien variabel sikap sebesar 0.42 dan koefisien

\footnotetext{
${ }^{14}$ Allen, J., Gregory, A., Mikami, A., Lun, J., Hamre, B., \& Pianta, R. (2013). Observations of effective teacherstudent interactions in secondary school classrooms: Predicting student achievement with the classroom assessment scoring system-secondary. School Psychology Review, 42(1), 76-98. doi: https://doi.org/10.1080/02796015.2013. 12087492

${ }^{15}$ Pianta, R. C., Hamre, B., \& Stuhlman, M. (2003). Relationships between teachers and children. Handbook of psychology, 199-234.

16 Pianta, R. C., \& Hamre, B. K. (2009). Conceptualization, measurement, and improvement of classroom processes: Standardized observation can leverage capacity. Educational researcher, 38(2), 109-119. doi: DOI: 10.3102/0013189X09332374

${ }^{17}$ Pianta, R. C., Hamre, B. K., \& Allen, J. P. (2012). Teacher-student relationships and engagement: Conceptualizing, measuring, and improving the capacity of classroom interactions Handbook of research on student engagement (pp. 365-386): Springer.

${ }^{18}$ Khilmiyah, A., Sumarno, S., \& Zuchdi, D. (2015). Pengembangan model penilaian keterampilan intrapribadi dan antarpribadi dalam pendidikan karakter di sekolah dasar. Jurnal Penelitian dan Evaluasi Pendidikan, 19(1), 1-12. doi: https://doi.org/10.21831/pep.v19i1.4550. Baca juga Marzuki, M., Zuchdi, D., Hajaroh, M., Imtihan, N., \& Wellyana, W. (2019). EVALUATING THE IMPLEMENTATION OF CHARACTER EDUCATION PROGRAM IN UNIVERSITY. Jurnal Kependidikan: Penelitian Inovasi Pembelajaran, 3(2). doi: 10.21831/jk.v3i2.25058. Ulfah, N., \& Zuchdi, D. (2015). Keefektifan Metode Komprehensif untuk Pengembangan Nilai Nasionalisme dalam Pembelajaran PPKn di SMPIT Abu Bakar Yogyakarta. Harmoni Sosial: Jurnal Pendidikan IPS, 2(2), 181-190. Zuchdi, D. Z. D. (2001). Pendekatan Pendidikan Nilaj secara Komprehensif sebagai suatu Alternatif Pembentukan Akhlak Bangsa. Jurnal Cakrawala Pendidikan, 2(2).
} 
variabel desain sebesar 0.93, hal ini menunjukkan bahwa desain perilaku memiliki pengaruh yang lebih besar di banding sikap yang dimiliki santri atau siswa. Terkait dengan adanya pengaruh yang besar antara desain nilai dengan perilaku, penelitian ini a didukung oleh hasil penelitian Chalim (2018), Lei, Lin, Deng, Dong, dan Luo (2020), Flook, Goldberg, Pinger, dan Davidson (2015). Hal lain yang terungkap juga dalam penelitian ini, bahwa nilai $\mathrm{R}^{2}$ adalah 0,83 artinya $83 \%$ perilaku keagamaan santri atau jamaah ditentukan oleh sikap dan desain perilaku keagamaan serta $17 \%$ sisanya ditentukan oleh variabel lain. ${ }^{19}$

Temuan di atas merupakan teori baru pembentukan perilaku keagamaan dalam bidang pendidikan. Sebelumnya Fishbein ${ }^{20}$ mengembangkan teori perilaku berencana yang merupakan perbaikan teori tindakan beralasan Fishbein yang menyatakan bahwa perilaku seseorang sangat ditentukan minat atau niat. ${ }^{21}$ Sedangkan niat dalam diri seseorang sangat ditentukan oleh sikap, norma subjektif dan control perilaku. Sikap adalah keyakianan akan perilaku atau keyakinan akan dampak dari perilaku yang terjadi.

Norma subjektif adalah pengaruh eksternal terhadap individu ketika akan melakukan sesuatu, seperti pengaruh guru atau teman. kontrol perilaku adalah dorongan atau hambatan ketika akan berperilaku yaitu berupa perasaan mudah atau susah untuk berperilaku. Teori tersebut banyak digunakan dalam kasus-kasus sosial ekonomi dan politik dengan konteks dan latar belakang kehidupan yang sangat heterogen seperti penelitian Kautonen, Van Gelderen, dan Tornikoski (2013), Paul, Modi, dan Patel (2016), Ajzen, Joyce, Sheikh, dan Cote (2011). ${ }^{22}$ Namun tentunya akan akan berbeda dan mengalami pergeseran bila teori berperilaku diterapkan dalam ranah yang homogen seperti dunia pendidikan.

Di lingkungan pendidikan, norma subjektif yang berupa pengaruh eksternal terhadap siswa merupakan bagian dari desain kurikulum. Desain kurikulum telah menetapkan target perilaku yang diharapkan, konten materi yang disiapkan untuk mewujudkan terbentuknya perilaku, aktivitas kegaiatan yang memberikan pengalaman belajar terkait dengan perilaku yang dimkasud dan penilaian disiakan untuk mengevaluasi apakah target perilaku yang dimaksud sudah tercapai atau belum. ${ }^{23}$ Untuk memunculkan kontrol perilaku yang positif

\footnotetext{
${ }^{19}$ Ghozali, I., \& Fuad, S. E. M. Teori, Konsep dan Aplikasi dengan Program Lisrel 9.10. (Badan Penerbit Universitas Diponegoro, 2014) Hal. 395

${ }^{20}$ Fishbein, M. A., Icek. (1980). Understanding attitude and predicting social behavior. Englewood Cliffs NJ: Prentice Hall.

${ }^{21}$ Fishbein, M. A., Icek. (1975). Belief, Attitude, Intention, dan Behavior: an introduction to theory and research. London: Addison, Wesley Publishing Company.

${ }^{22}$ Kautonen, T., Van Gelderen, M., \& Tornikoski, E. T. (2013). Predicting entrepreneurial behaviour: a test of the theory of planned behaviour. Applied Economics, 45(6), 697-707. doi: https://doi.org/10.1080/00036846.2011.610750. Baca juga Paul, J., Modi, A., \& Patel, J. (2016). Predicting green product consumption using theory of planned behavior and reasoned action. Journal of retailing and consumer services, 29, 123-134. doi: https://doi.org/10.1016/j.jretconser.2015.11.006. Ajzen, I., Joyce, N., Sheikh, S., \& Cote, N. G. (2011). Knowledge and the prediction of behavior: The role of information accuracy in the theory of planned behavior. Basic and applied social psychology, 33(2), 101-117. doi: https://doi.org/10.1080/01973533.2011.56883

${ }^{23}$ Hadi, S., Andrian, D., \& Kartowagiran, B. (2019). Evaluation Model for Evaluating Vocational Skills Programs on Local Content Curriculum in Indonesia: Impact of Educational System in Indonesia. Eurasian Journal of Educational Research, 82, 45-61. doi: 10.14689/ejer.2019.82.3. Baca juga Qomari, R. (2016). The Evaluation of Curriculum Implementation on Islamic Higher Education in Indonesia. Ijtimā'iyya: Journal of Muslim Society Research, 1(1), 97-112. doi: https://doi.org/10.24090/ijtimaiyya.v1i1.929. Zhao, D., Ma, X., \& Qiao, S. (2017). What aspects should be evaluated when evaluating graduate curriculum: Analysis based on student interview. Studies in Educational Evaluation, 54, 50-57. doi:
} 
berupa perasaan mudah untuk berperilaku maka dalam aktivitas pembelajaran guru membutuhkan dukungan emosi dan menggunakan teknik inkulkasi nilai yang mampu memberikan keyakinan sehingga memunculkan perasaan mudah untuk berperilaku. ${ }^{24}$ Dengan demikian teori berperilaku dalam pendidikan merupakan pergeseran teori perilaku beralasan dalam konteks social, ekonomi dan politik.

\section{PEMBAHASAN}

Perilaku keagamaan siswa ditentukan oleh sikap dan desain kurikulum di sekolah. Sikap sangat berpengaruh terhadap perilaku. Demikian pula desain nilai keagamaan dalam kurikulum sangat menentukan perilaku yang menjadi tujuan pembentukan nilai.

Namun demikian hanya sikap yang dipandu oleh kurikulum dan dijalankan dengan proses yang benar yang akan membentuk perilaku keagmaan siswa seperti yang dikehendaki. Proses pembentukan sikap yang akan mendorong siswa berperilaku seperti yang dikehendaki adalah proses yang menggabungkan dua konsep yaitu teori interaksi dan teori pendidikan nilai. ${ }^{25}$ Proses pembelajaran membutuhkan dukungan teori interaksi guru dan siswa yang mencakup dukungan emosional, dukungan instruksional dan manajemen kelas. ${ }^{26}$ Perilaku keagamaan juga hanya akan terbentuk bila proses interaksi guru dan siswa menggunakan metode komprehensif yang meliputi inkulkasi nilai, keteladanan, fasilitasi nilai dan pengembangan ketrampilan sosial akademik. Proses interaksi harus dipandu dengan desain kurikulum yang memauat nilai-nilai keagamaan organisasi.

Pada konsteks kehidupan sosial seperti aliran sesat dan organisasi keagamaan, perilaku jamaah sangat ditentukan oleh sikap dan pandangan yang diyakini jamaah serta desain perilaku yang diinginkan berdasarkan kitab yang dijadikan pedoman organisasi. Sementara itu, munculnya sikap dan pandangan keagamaan sangat ditentukan oleh proses dan desain sikap yang diinginkan. Proses yang berkualitas yaitu adanya dukungan emosional, manajemen kelas dan dukungan instruksional akan membuat proses internalisasi berjalan optimal. Dan, akan lebih optimal lagi apabila menggunakan metode komprehensif dalam penguatan sikap.

Metode komprehensif merupakan metode pendidikan nilai yang mengedepankan rasionalitas bukan doktrinal. Metode ini meliputi inkulkasi nilai, keteladanan, fasilitasi nilai dan pengembangan ketrampilan sosial dan akademik. ${ }^{27}$ Inkulkasi nilai menuntut guru, pimpinan jamaah mampu

ttps://doi.org/10.1016/j.stueduc.2016.11.003

${ }^{24}$ Khilmiyah, A., Sumarno, S., \& Zuchdi, D. (2015). Pengembangan model penilaian keterampilan intrapribadi dan antarpribadi dalam pendidikan karakter di sekolah dasar. Jurnal Penelitian dan Evaluasi Pendidikan, 19(1), 1-12. doi: https://doi.org/10.21831/pep.v19i1.4550. Baca juga Marzuki, M., Zuchdi, D., Hajaroh, M., Imtihan, N., \& Wellyana, W. (2019). EVALUATING THE IMPLEMENTATION OF CHARACTER EDUCATION PROGRAM IN UNIVERSITY. Jurnal Kependidikan: Penelitian Inovasi Pembelajaran, 3(2). doi: 10.21831/jk.v3i2.25058. Ulfah, N., \& Zuchdi, D. (2015). Keefektifan Metode Komprehensif untuk Pengembangan Nilai Nasionalisme dalam Pembelajaran PPKn di SMPIT Abu Bakar Yogyakarta. Harmoni Sosial: Jurnal Pendidikan IPS, 2(2), 181-190. Zuchdi, D. Z. D. (2001). Pendekatan Pendidikan Nilaj secara Komprehensif sebagai suatu Alternatif Pembentukan Akhlak Bangsa. Jurnal Cakrawala Pendidikan, 2(2).

${ }^{25}$ Zuchdi, D. (1995). Pembentukan sikap. Cakrawala Pendidikan, 83690.

${ }^{26}$ Pianta, R. C., Hamre, B., \& Stuhlman, M. (2003). Relationships between teachers and children. Handbook of psychology, 199-234. Baca juga Pianta, R. C., \& Hamre, B. K. (2009). Conceptualization, measurement, and improvement of classroom processes: Standardized observation can leverage capacity. Educational researcher, 38(2), 109-119. doi: DOI: 10.3102/0013189X09332374. Pianta, R. C., Hamre, B. K., \& Allen, J. P. (2012). Teacher-student relationships and engagement: Conceptualizing, measuring, and improving the capacity of classroom interactions Handbook of research on student engagement (pp. 365-386): Springer.

${ }^{27}$ Zuchdi, D. Z. D. (2001). Pendekatan Pendidikan Nilaj secara Komprehensif sebagai suatu Alternatif 
menyampaikan argumen secara rasional, memperlakukan jamaah dengan adil. Dalam hal keteladanan guru harus menjadi model bagi jamaah.

\section{KESIMPULAN}

Penelitian ini menghasilkan teori perilaku keagamaan di sekolah yaitu bahwa perilaku keagamaan ditentukan oleh sikap dan desain kurikulum. Sikap yang mampu mempengaruhi perilaku yaity sikap yang dibentuk melalui proses penguatan nilai dan keyakinan organisasi dan dipandu dengan desain kurikulum yang memuat nilai dan keyakinan tersebut. Proses pembelajaran yang mampu menguatkan nilai dan keyakinan siswa bila mengkombinasikan interkasi guru-siswa dengan metode pendidikan nilai dalam pembelajaran.

Interaksi guru dan siswa akan berkualitas bila menghadirkan dukungan emosional, dukungan instruksional dan manajemen kelas yang baik. Sedangkan pendidikan nilai dapat diadopsi untuk memperkuat instruksional guru melalui metode inkulkasi, keteladanan, fasilitasi nilai dan pengembangan ketrampilan sosial-akademik. Sedangkan desain kurikulum yang mencerminkan kurikulum nilai dan keyakinan organisasi apabila dari aspek tujuan terkait dengan penguatan nilai organisasi, aspek konten menghadirkan nilai organisasi, dari aspek proses menggunakan metode komprehensi dan dari penilaian mencakup aspek bahwa evaluasi untuk memotret ketercapaian kurikulum dari tujuan yang ditetapkan.

\section{DAFTAR PUSTAKA}

Ajzen, I., Joyce, N., Sheikh, S., \& Cote, N. G. (2011). Knowledge and the prediction of behavior: The role of information accuracy in the theory of planned behavior. Basic and applied social psychology, 33(2), 101-117. doi: https://doi.org/10.1080/01973533.2011.568834

Allen, J., Gregory, A., Mikami, A., Lun, J., Hamre, B., \& Pianta, R. (2013). Observations of effective teacher-student interactions in secondary school classrooms: Predicting student achievement with the classroom assessment scoring system-secondary. School Psychology Review, 42(1), 76-98. doi: https://doi.org/10.1080/02796015.2013.12087492

Azwar, S. (2007). Sikap manusia. Teori dan Pengukurannya, Pustaka Pelajar, Yogyakarta. Chalim, S. (2018). Pengaruh Misi, Kurikulum, Dan Kepemimpinan Di Perguruan Tinggi Terhadap Perilaku Anti-Radikalisme Mahasiswa. Jurnal Pendidikan dan Kebudayaan, 3(1), 261678. doi: 10.24832/jpnk.v3i1.728

Darma, I. K. (2019). The effectiveness of teaching program of CIPP evaluation model. International research journal of engineering, IT \& scientific research, 5(3), 1-13. doi: https://doi.org/10.21744/irjeis.v5n3.619

Fishbein, M. A., Icek. (1975). Belief, Attitude, Intention, dan Behavior: an introduction to theory and research. London: Addison, Wesley Publishing Company.

Fishbein, M. A., Icek. (1980). Understanding attitude and predicting social behavior. Englewood Cliffs NJ: Prentice Hall.

Flook, L., Goldberg, S. B., Pinger, L., \& Davidson, R. J. (2015). Promoting prosocial 
behavior and self-regulatory skills in preschool children through a mindfulness-based

Kindness Curriculum. Developmental psychology, 51(1), 44. doi: https://doi.org/10.1037/a0038256

Ghozali, I., \& Fuad, S. E. M. (2014). Teori, Konsep dan Aplikasi dengan Program Lisrel 9.10 .

Badan Penerbit Universitas Diponegoro.

Gultom, M., Sumarno, S., \& Madya, S. (2014). Model Evaluasi Reflektif Kurikulum Pendidikan Bahasa Inggris Dalam Pengembangan Karakter Bangsa. Jurnal Penelitian dan Evaluasi Pendidikan, 18(1), 72-88. doi: https://doi.org/10.21831/pep.v18i1.2125

Hadi, S., Andrian, D., \& Kartowagiran, B. (2019). Evaluation Model for Evaluating Vocational Skills Programs on Local Content Curriculum in Indonesia: Impact of Educational System in Indonesia. Eurasian Journal of Educational Research, 82, 4561. doi: 10.14689/ejer.2019.82.3

Imansari, N., \& Sutadji, E. (2017). A Conceptual Framework Curriculum Evaluation Electrical Engineering Education. International Journal of Evaluation and Research in Education, 6(4), 265-269.

Kautonen, T., Van Gelderen, M., \& Tornikoski, E. T. (2013). Predicting entrepreneurial behaviour: a test of the theory of planned behaviour. Applied Economics, 45(6), 697707. doi: https://doi.org/10.1080/00036846.2011.610750

Kavgaoglu, D., \& Alci, B. (2016). Application of Context Input Process and Product Model in Curriculum Evaluation: Case Study of a Call Centre. Educational Research and Reviews, 11(17), 1659-1669. doi: DOI: 10.5897/ERR2016.2911

Khilmiyah, A., Sumarno, S., \& Zuchdi, D. (2015). Pengembangan model penilaian keterampilan intrapribadi dan antarpribadi dalam pendidikan karakter di sekolah dasar. Jurnal Penelitian dan Evaluasi Pendidikan, 19(1), 1-12. doi: https://doi.org/10.21831/pep.v19i1.4550

Khuriyah, K., Zamroni, Z., \& Sumarno, S. (2016). PENGEMBANGAN MODEL EVALUASI PENGELOLAAN PONDOK PESANTREN. Jurnal Penelitian dan Evaluasi Pendidikan, 20(1), 56-69. doi: https://doi.org/10.21831/pep.v20i1.7529

Latan, H. (2013). Structural equation modeling: Konsep dan aplikasi menggunakan program LISREL 8.80. Bandung: Alfabeta.

Lei, L., Lin, L., Deng, J., Dong, H., \& Luo, Y. (2020). Developing an organ donation curriculum for medical undergraduates in china based on theory of planned behavior: a delphi method study. Annals of transplantation, 25, e922809-922801. doi: 10.12659/AOT.922809

Marzuki, M., Zuchdi, D., Hajaroh, M., Imtihan, N., \& Wellyana, W. (2019). EVALUATING THE IMPLEMENTATION OF CHARACTER EDUCATION PROGRAM IN UNIVERSITY. Jurnal Kependidikan: Penelitian Inovasi Pembelajaran, 3(2). doi: $10.21831 / \mathrm{jk} . v 3 \mathrm{i} 2.25058$

Matondang, H. A., \& Rangkuti, S. M. (2020). Kajian dan Penelitian Fatwa-Fatwa Mui Tentang Aliran Sesat. Medan: CV Manhaji.

Paul, J., Modi, A., \& Patel, J. (2016). Predicting green product consumption using theory of planned behavior and reasoned action. Journal of retailing and consumer services, 29, 123-134. doi: https://doi.org/10.1016/j.jretconser.2015.11.006 
Pianta, R. C., Hamre, B., \& Stuhlman, M. (2003). Relationships between teachers and children. Handbook of psychology, 199-234.

Pianta, R. C., \& Hamre, B. K. (2009). Conceptualization, measurement, and improvement of classroom processes: Standardized observation can leverage capacity. Educational researcher, 38(2), 109-119. doi: DOI: 10.3102/0013189X09332374

Pianta, R. C., Hamre, B. K., \& Allen, J. P. (2012). Teacher-student relationships and engagement: Conceptualizing, measuring, and improving the capacity of classroom interactions Handbook of research on student engagement (pp. 365-386): Springer.

Qomari, R. (2016). The Evaluation of Curriculum Implementation on Islamic Higher Education in Indonesia. Ijtimā'iyya: Journal of Muslim Society Research, 1(1), $97-$ 112. doi: https://doi.org/10.24090/ijtimaiyya.v1i1.929

Subando, J., Kartowagiran, B., \& Munadi, S. (2020a). Constructions of Al-Irsyad's Ideology. Paper presented at the International Conference of Social Sciences and Education 2020, Yogyakarta, Indonesia.

Subando, J., Kartowagiran, B., \& Munadi, S. (2020b). The Development of Instrument for Evaluating The Process of Strengthening Religion Ideology. Paper presented at the Proceedings of the 4th International Conference on Learning Innovation and Quality Education.

Subando, J., Kartowagiran, B., \& Munadi, S. (2020c). Pengembangan Instrumen Indeks Ketahanan Ideologi Al-Irsyad Komponen Perilaku. Prosiding Seminar virtual pendidikan Kewarganegaraan 2020 UNS, 1(1), 406-413.

Ulfah, N., \& Zuchdi, D. (2015). Keefektifan Metode Komprehensif untuk Pengembangan Nilai Nasionalisme dalam Pembelajaran PPKn di SMPIT Abu Bakar Yogyakarta. Harmoni Sosial: Jurnal Pendidikan IPS, 2(2), 181-190.

Zhao, D., Ma, X., \& Qiao, S. (2017). What aspects should be evaluated when evaluating graduate curriculum: Analysis based on student interview. Studies in Educational Evaluation, 54, 50-57. doi: https://doi.org/10.1016/j.stueduc.2016.11.003

Zuchdi, D. (1995). Pembentukan sikap. Cakrawala Pendidikan, 83690.

Zuchdi, D. Z. D. (2001). Pendekatan Pendidikan Nilaj secara Komprehensif sebagai suatu Alternatif Pembentukan Akhlak Bangsa. Jurnal Cakrawala Pendidikan, 2(2). 